\title{
Palynological Zonations and Sequence Stratigraphic Analysis of Sediments in Benin West-1, Anambra Basin, Nigeria
}

\author{
O. Odedede", J. E. Ogala, F. C. Ugbe \\ Department of Geology, Delta State University, Abraka, Delta State, Nigeria
}

Received 29 September 2015, accepted in final revised form 30 January 2016

\begin{abstract}
Palynoflora analyses from Benin west -1, Anambra Basin has unfold three palynozones based on abundance, composition of palynoflora and cluster analysis. Palynozone-1 has been dated as Late Maastrichtian age and belong to the lowermost Imo Shale, palynozone2; Middle Eocene and palynozone -3 is dated Lutetian to Bartonian age. Sediments between depth intervals of $2649-2560 \mathrm{~m}$ is marked a sequence boundary, $1650-2560 \mathrm{~m}$, and $970-1190 \mathrm{~m}$ is delineated as high stand system tract. Shaly intervals from the depth of $1644 \mathrm{~m}$, and $1234 \mathrm{~m}$ recorded acme of palynoflora (Zonocostites ramonae, Monoporites annulatus, Verrucatosporites spinosus, Botryococcus braunii) and probably fingerprints a condensed section. The condensed section intervals (1644 $\mathrm{m}$ and $1234 \mathrm{~m})$ may depict good source rock and exploration targets.
\end{abstract}

Keywords: Late Maastrichtian; Middle Eocene; Palynological; Palynozones; Sequence boundary.

(C) 2016 JSR Publications. ISSN: 2070-0237 (Print); 2070-0245 (Online). All rights reserved. doi: http://dx.doi.org/10.3329/jsr.v8i2.25180 J. Sci. Res. 8 (2), 171-179 (2016)

\section{Introduction}

Palynological zonation is the characterization and subdivision of sedimentary strata on the basis of palynofossils content. This differentiation allows small scale units to be dated, correlated and interpreted within a precise framework of geologic time. According to Aswal, palynofossils play a very significant role in dating sequence stratigraphic surfaces and in understanding the process sedimentology [1]. The Anambra Basin has been investigated by previous workers [2,3] as a result of renewed interest in the exploration for oil and gas due to Federal Government of Nigeria comparative advantage for these resources. This necessitated the revisit to abandon well (Benin west-1). The aim of this work is to determine the palynomorph composition, establish the zonation, date with a view to establish sequence stratigraphic framework.

*Corresponding author: odededeo@yahoo.com 


\section{Study Area and Geological Setting}

The studied area (Fig.1) is located in the northern part of Anambra Basin where sediments of Imo and Ameki Formation were encountered. Anambra Basin evolved tectonically after the Santonian tectonism that affected the Benue Trough, characterized by uplift of the Abakaliki structure and subsequent downward displacement of the Anambra Platform and Afikpo Syncline, trending SW and SE of the Abakaliki structure [2,4].

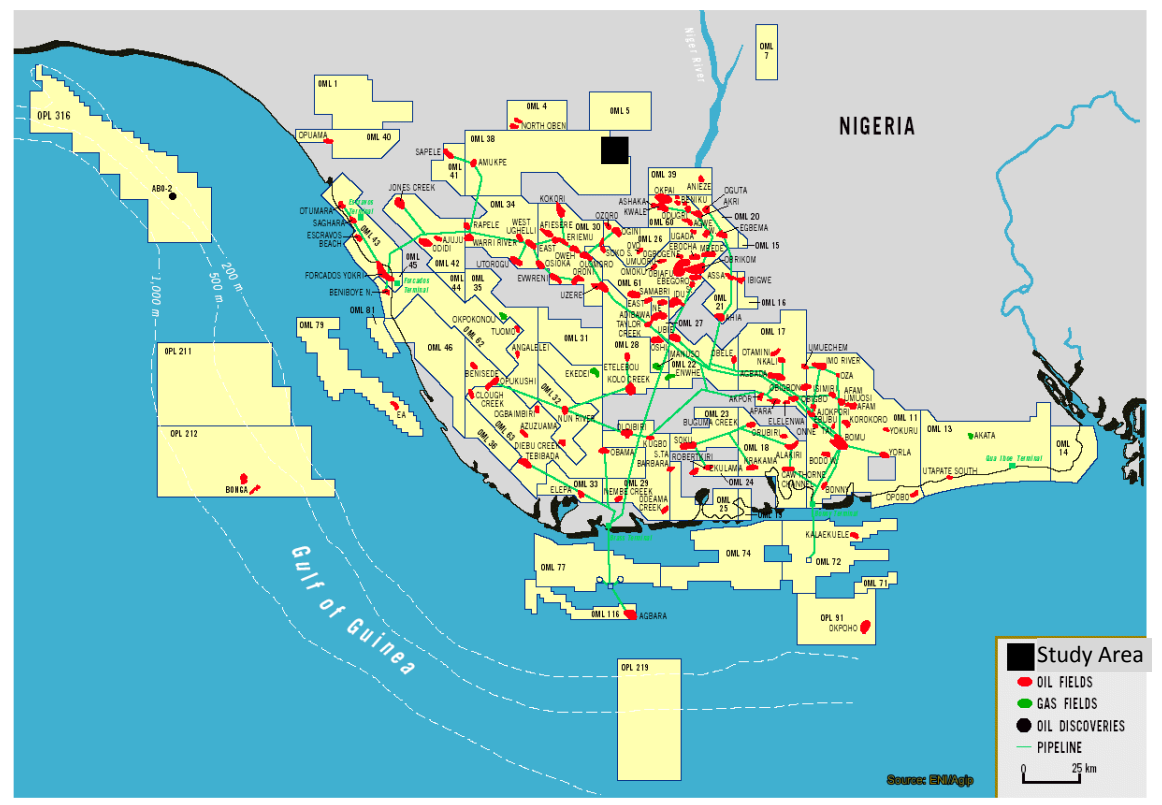

Fig. 1. Map of Niger Delta showing location of Benin West- 1 [modified after 3].

\section{Materials and Methods of Study}

Twenty-seven ditch cuttings of Benin west-1 well were selected based on stratigraphic position and sedimentary attributes. Samples were screened palynologically following the procedure reported elsewhere [5]. Samples were digested with $30 \mathrm{~mL}$ of $10 \% \mathrm{HCl}$ to remove carbonates. It was then digested with $30 \mathrm{ml}$ of $40 \% \mathrm{HF}$ for $24 \mathrm{~h}$ to remove silica, filtered with 10 microns sieve with water, oxidized and separated from debris with the use of $\mathrm{ZnCl}_{2}$. Palynoflora residuum were set on glass slides and examined for palynofossils with the aid of Mieji binocular microscope. Identification of forms were made possible by correlating it with published works [6]. Palynological forms recorded in the selected section aided the creation of sequence stratigraphic framework. Palynological association were also obtained from cluster analysis using the agglomerative method [7]. 


\section{Results and Discussion}

Relative ages deduced from the palynoflora (Table 1, Figs. 2 - 4) were derived from earlier reported palynoflora works [6,8,9]. Benin west-1 recorded 42 species of palynoflora counts and displayed a diverse pattern of palynoflora (Figs. 2-4) allowing a subdivision of the Imo shale and Ameki Formation into three (3) zones (Figs. 3-4) based on the first occurrences of two or more forms (Fig. 5).

Zone 1: The base of the sequence $(1854-2607 \mathrm{~m})$ is marked by the occurrence of Zlivisporites blanensis, Lycopodium phlegmaria, Pachydermites diederixi Psilatricolporites sp., Retribrevitricolporites protrudens, Laevigatosporites sp., and Leiotriletes sp. Dinoflagellate cysts (Fig. 5) dominates the top of the sequence and is equivalent to the P1 zone [10]. Palynostratigraphic data suggest Late Maastrichtian age and belong to the lowermost Imo Shale (Fig. 5).

Zone 2: The top of the zone is characterized by the occurrence of Nyphae lotus and Restistephanocolpites gracilis. Other miospores associated with this interval include Elaesis guineensis, Pteris sp., Multiareolites formosus and Retibreviticolporites protrudens. It is subdivided into four subzones equivalent to P430 [9] and is dated Middle Eocene.

Zone 3: This zone is associated with the top of the Imo Shale (1234-1034 m) and part of the Ameki Formation (972-324 m). It is subdivided into two subzones, characterized by the occurrence of Monoporites annulatus, Operculodinium giganteum, and Selenopemphix nephroides. This zone is similar to P300-P400 zones described in literature [9,11]. This zone is dated Lutetian - Bartonian age (Fig. 5). A total of three zones and six subzones have been recognized in the Benin west-1. Statistically, three assemblages/association were also recognized (Fig. 6). The first assemblage (1) is composed of mangrove and freshwater elements (Monoporites annulatus, Botrycoccus braunii). The second assemblage (2) is composed of mixture of marine, mangrove palynoflora while the third (3) associations are made up of marine components (dinoflagellate cyst, microforaminifera wall linings and Nympha lotus). These associations of mixed palynoflora, probably suggests a transgressive - regressive conditions. This scheme corroborates the line of evidence from palynostratigraphy. 


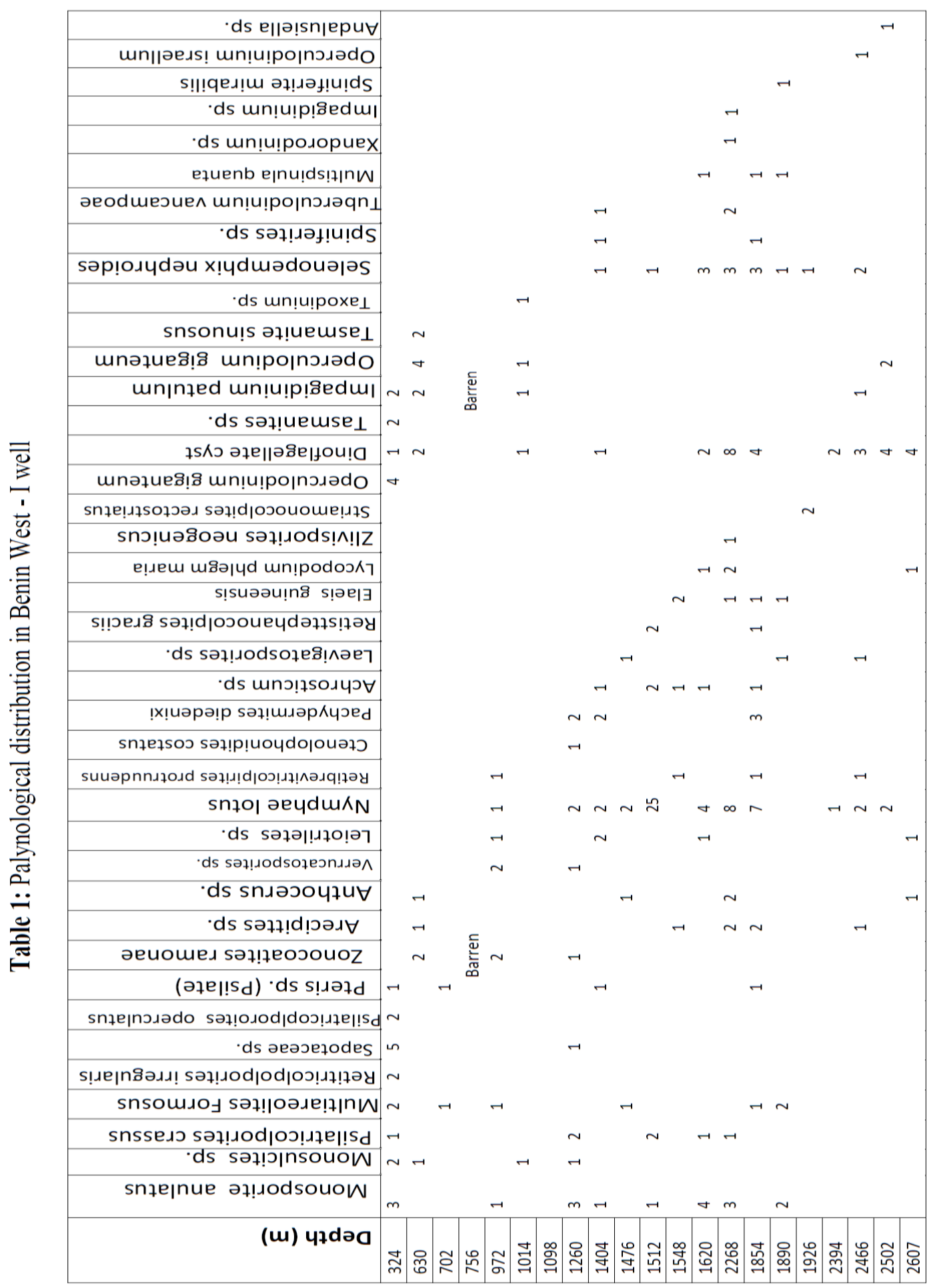




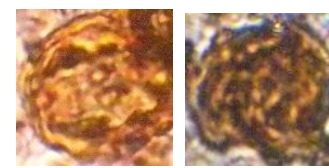

2
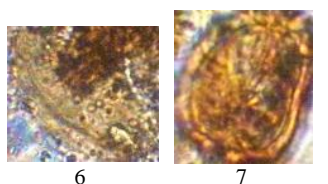

7

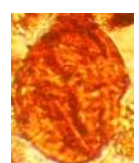

3

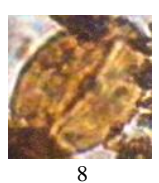

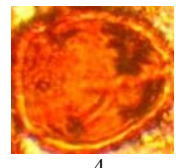
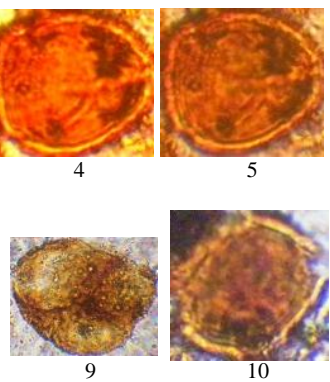

$6 \quad$ Monosulcites sp

7 Monoporites annulatus

$8 \quad$ Monocolpites sp

$9 \quad$ Microforaminiferal wall lining

10 Pachydermites diederixi

Fig. 2. Photomicrographs of some characteristic Palynomorphs associated with Benin West -1 , Benin Flank.

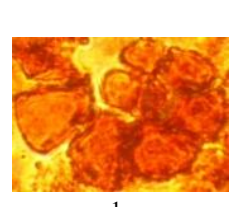

1

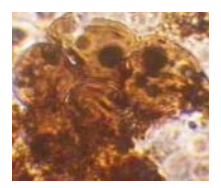

1

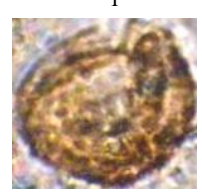

5

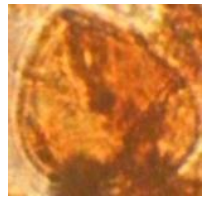

9

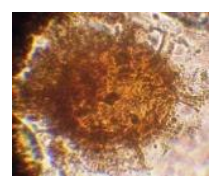

2

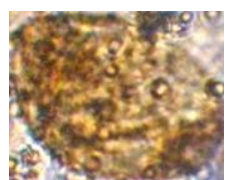

2

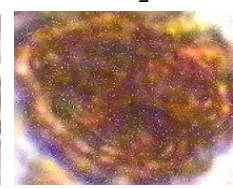

6

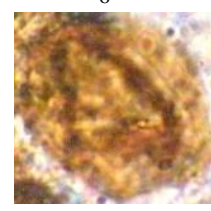

10

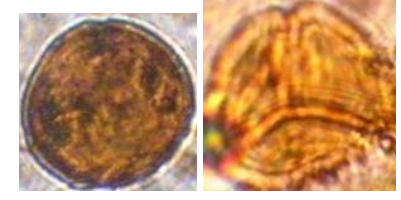

4

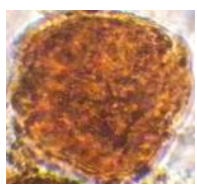

3

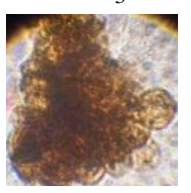

7

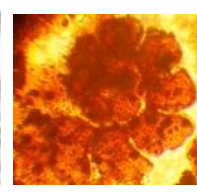

4

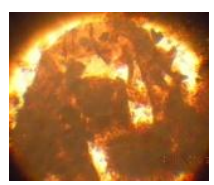

8
1 Microforaminiferal wall lining

2 Psilatricolporites crassus

3 Elaeis guineensis

4 Microforaminiferal wall lining

5 Nymphae lotus
6 Retistephanocolpites gracilis

7 Polyadadpolinites sp of Nymphae lotus

8 Nymphae lotus

9 Leiotriletes sp

10 Monoporites annulatus

Fig. 3. Photomicrographs of some characteristic Palynomorphs associated with Benin West-1, Benin Flank. 

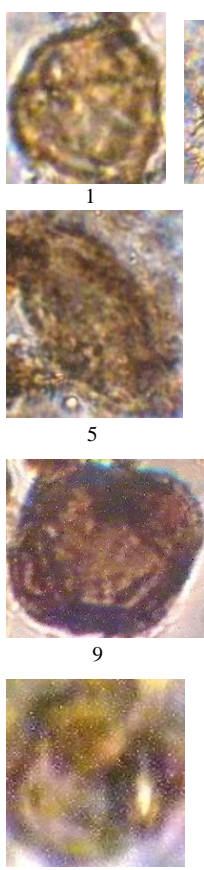

13

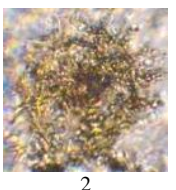

2
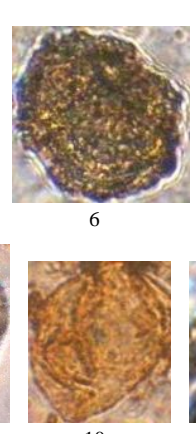

10

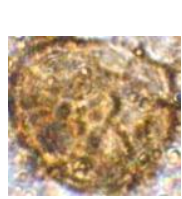

14
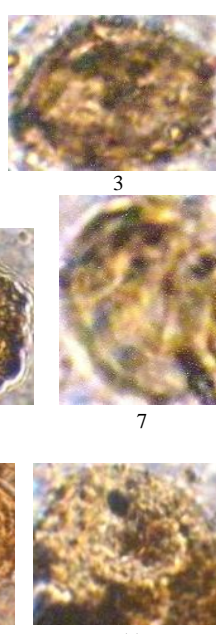

11

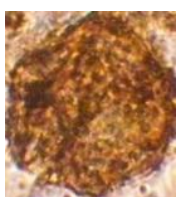

15
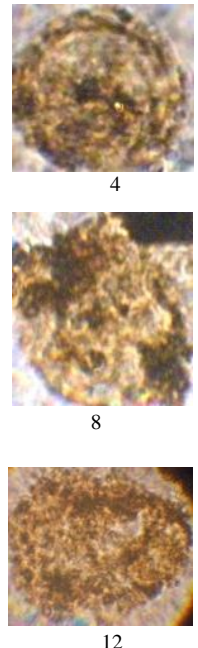

12

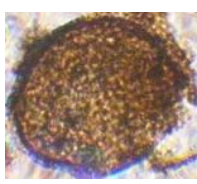

16
1 Nymphae lotus

2 Xandorodinium sp

3 Monoporites annulatus

4 Lycopodium phlegmaria

5 Arecipites sp

6 Retibravitricolporites protrudens

7 Nymphae lotus

8 Indeterminate
9,10 Selenopenphix nephroides

11,12 Tuberculodinium vancampoae

13 Zonocostites ramonae

14 Impagidinium sp A

15 Psilatricolporites crassus

16 Spirosyncolporites $\mathrm{sp}$

Fig. 4. Photomicrographs of some characteristic Palynomorphs associated with Benin West -1 , Benin Flank.

\section{Sequence Stratigraphic Framework of Benin West-1}

The Benin west -1 well sediments are composed of the following sequences:

Sequence Boundary- Sandstone at the depth of 2649-2560 m (Fig. 3) recorded lean population of palynoflora. It consists of granules and crystalline fragments. This marks the boundary with the overlying HST sediments and is dated 64.2-64.8 Ma.

Highstand System Tract (HST) - The highstand systems tract (1650-2560 m, and 970$1190 \mathrm{~m}$ ) constitutes the lower and upper parts of Imo shale (Fig.5).. It lies directly on the sequence boundary, flooding surface and contains palynormophs such as Psilatricolporites crassus Pachydermites diederixi, Zonocostites ramonae and Botryococcus braunii with percentage of 3.4 to $5 \%$, probably represents a relative fall in sea level. Its numerical age is assigned 47.2-50.6 Ma [10,12]. The stacking pattern 
indicates early rise or fall in sea level and the shaly portion may be a potential source rocks.

Flooding Surface -The depth of $1644 \mathrm{~m}, 1234 \mathrm{~m}$ (Fig. 5) is made up of shale and documented high populations of palynormophs. This unit probably represents a condensed section associated with flooding surface. It is characterized by the maximum abundance $(10 \%)$ and diversity $(8.72-9.39 \%)$. Palynoflora affiliated with the flooding surface include Zonocostites ramonae, Monoporites annulatus, Verrucatosporites spinosus and Botryococcus braunii. These intervals may constitute the sequence with high quality organic matter and is assigned $51 \mathrm{Ma}$ [12-14].

Transgressive Systems Tract (TST) - The trangressive systems tract lies directly on the flooding surface and highstand systems tract. Depth interval of 1244-1634 m and 134-934 m (Ameki Formation) marks the trangressive systems tract. It contains palynormophs such as Verrucatosporite spinosus, Monoporites annulatus, Botryococcus braunii and is assigned 37-47.4 Ma [12-14].

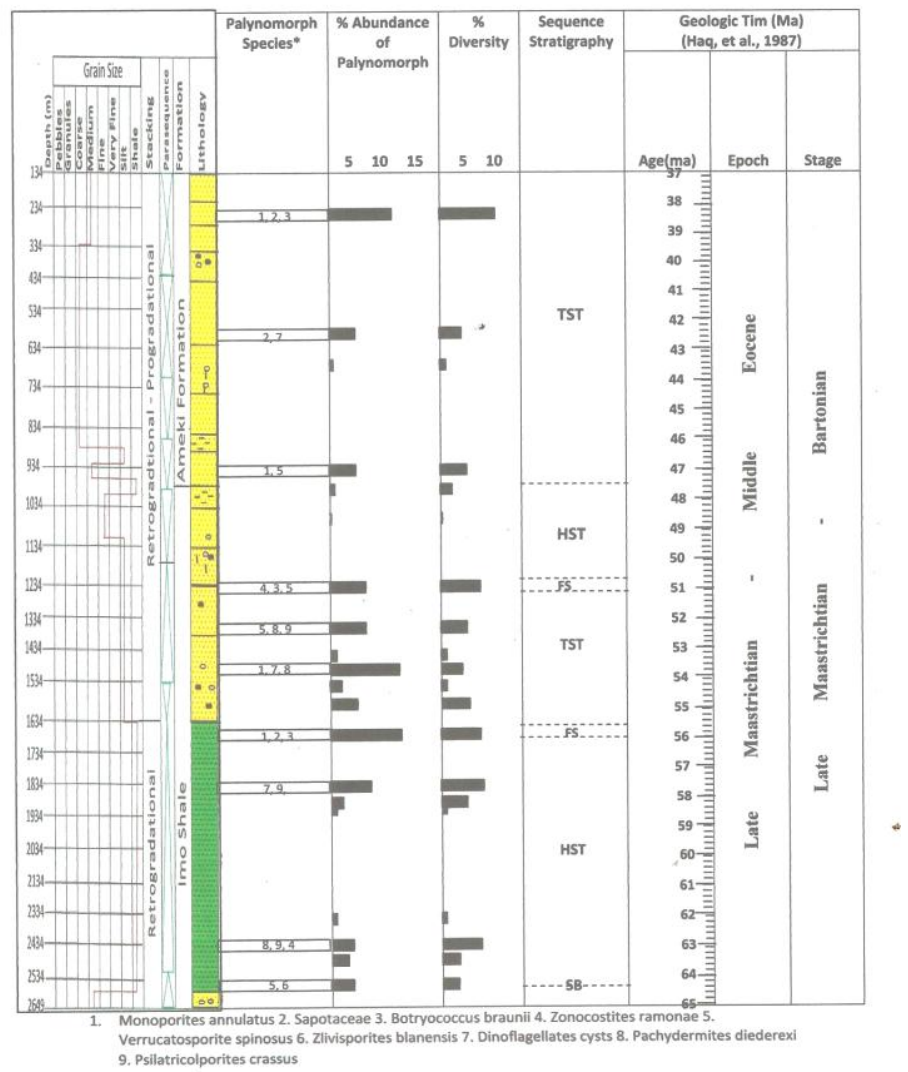

Fig. 5. A proposed sequence stratigraphic framework of benin west -1 , based on abundance and diversity of palynomorphs at depth. 


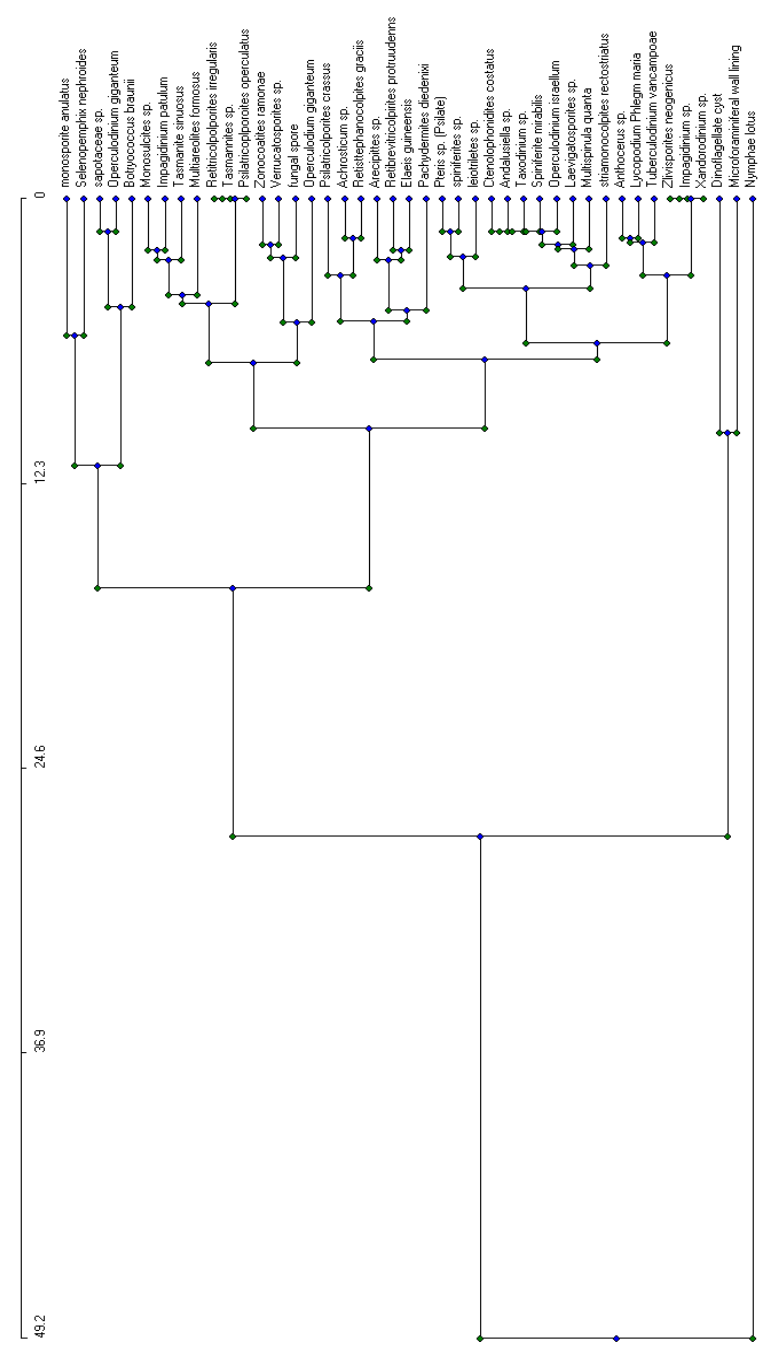

Fig. 6. Dendrogram showing the results of the cluster analysis on statistical significant Palynoflora taxa and their assemblages for Benin west-1.

\section{Conclusion}

Three palynological zones have been established in the studied area. Palynozone-1 has been dated as Late Maastrichtian age and belong to the lowermost Imo Shale, palynozone2 dated Middle Eocene and palynozone-3 is dated Lutetian to Bartonian age. A total of three palynozones and six subzones have been recognized. Sequence boundary (2649$2560 \mathrm{~m})$, highstand system tract (1650-2560 m, and 970-1190 m) and shaly intervals at 
the depth of $1644 \mathrm{~m}$, and $1234 \mathrm{~m}$ recorded spike of palynormophs (Zonocostites ramonae, Monoporites annulatus, Verrucatosporites spinosus and Botryococcus braunii) and probably represents a condensed section.

\section{References}

1. H. S. Aswal, in Palynology- A non-Seismic Method in Hydrocarbon Exploration - $9^{\text {th }}$ Biennial Int. Conference and Exposition on Petroluem Geophysics (Hyderabad, India, 2012).

2. A. J. Edegbai and W. O. Emofurieta, Ife J. Sci. 17(1), 131 (2015).

3. F. A. Lucas and O. M. Odedede, World J. Eng. 9(6), 513 (2012). http://dx.doi.org/10.1260/17085284.9.6.513

4. T. J. A. Reijers, S. W. Petters, and C. S. Nwajide, The Niger Delta Basin, In: Sedimentary Basins of the World (Elsevier, 1997) 3, pp. 151-172.

5. G. D. Wood, A. M. Gabriel, and J. C. Lawson, Palynological Techniques - Processing and Microscopy, in J. Jansonius and D. C. McGregor, ed. Palynology: Principles and Applications (American Association of Stratigraphic Palynologists Foundation, 1996) 1, pp. 29.

6. R. Jan du Chêne, M. S.Onyike and M. A. Sowumi, Revista De Espanol Micro Paleontologie 10, 285 (1978).

7. W. L. Kovach, Rev. Paleobotany Palynology, 60, 25 (1989). http://dx.doi.org/10.1016/00346667(89)90046-8

8. T. A. V. Hammen, Leidese Geologiche Mededelingen 29, 125 (1963).

9. D. D. Evamy, J. Haremboure, P. Kemerling, W. A. Knaap, F. A. Molly, and P. H. Rowlands, Am. Assoc. Petroleum Geologist Bull. 62, 1 (1978).

10. J. Hardenbol and W. A. Berggren, A New Plaleogene Numerical Time Scale. Am. Assoc. Petroleum Geologists Studies in Geology, 6, 234 (1978)

11. J. J. Germeraad, C. A. Hoppings, and J. Muller, Rev. Paleobotany and Palynology 3/4, 187 (1968). http://dx.doi.org/10.1016/0034-6667(68)90051-1

12. B. U. Haq, J. Hardenbol, and P.R. Vail, J. Sci. 235, 1156 (1987). http://dx.doi.org/10.1126/science.235.4793.1156

13. O. Odedede, F. A Lucas, and G.O. Asuen, J. Mining Geol. 48(2), 185 (2012).

14. O. Odedede, J. Eng. Res. 3(1), 137 (2015). http://dx.doi.org/10.7603/s40632-015-0008-5 